\title{
Clinical features and outcome of adult T-cell leukemia/lymphoma: University of Miami experience
}

\author{
Agustin Pimentel ${ }^{1}$, Isildhina Reis ${ }^{2}$, Jennifer R Chapman-Fredricks ${ }^{3}$, Juan Carlos Ramos ${ }^{1 *}$ \\ From 16th International Conference on Human Retroviruses: HTLV and Related Viruses \\ Montreal, Canada. 26-30 June 2013
}

Adult T-cell leukemia/lymphoma (ATLL) is an aggressive malignancy with a poor prognosis caused by HTLV-I. Miami is proximal to the Caribbean, where HTLV-I is endemic. We have identified at least 140 cases between 1987 and 2013. A total of 108 patients have been analyzed for treatment response, including 51 acute, 50 lymphomatous, 5 chronic ( 4 unfavorable), and 2 smoldering types. The median overall survival for acute and lymphomatous was 6 and 10 months respectively, and not reached for chronic and smouldering types. Fifty-one patients (33 acute, 11 lymphomatous, 5 chronic, and 2 smouldering) were treated with high-dose AZT/interferon (IFN) as first line therapy. The complete and overall response rates $(\mathrm{CR}$ and ORR) for acute/unfavorable chronic vs. lymphomatous types were $27 \%$ vs. $9 \%$, and $57 \%$ vs. $9 \%$ respectively. Three out of 4 (75\%) unfavorable chronic type patients responded to AZT/IFN (2 CR, and 1 partial response). Seventy-three patients received chemotherapy at some point during their treatment. The CR rate and ORR for acute/unfavorable chronic vs. lymphomatous-type patients treated with chemotherapy-based regimens were $33 \%$ vs. $17 \%$, and $60 \%$ vs. $73 \%$ respectively. Five acute type patients who had failed AZT/IFN achieved remission after chemotherapy. By contrast, patients treated with AZT/IFN as second line therapy generally did not respond. Finally, we observed several long-sustained responses in acute and unfavorable chronic subtypes treated with first line AZT/ IFN alone translating into a survival benefit. A comprehensive stratified analysis of clinical characteristics, pertinent immunophenotypic markers, and treatment outcome will be presented at the meeting.

\footnotetext{
* Correspondence: jramos2@med.miami.edu

'Division of Hematology-Oncology, Department of Medicine, Sylvester

Comprehensive Cancer Center, University of Miami, Miami, FL, USA
}

Full list of author information is available at the end of the article

\section{Authors' details}

'Division of Hematology-Oncology, Department of Medicine, Sylvester Comprehensive Cancer Center, University of Miami, Miami, FL, USA. ${ }^{2}$ Department of Epidemiology \& Public Health, University of Miami Miller School of Medicine and Jackson Memorial Hospital, Miami, FL, USA. ${ }^{3}$ Department of Pathology and Laboratory Medicine, University of Miami Miller School of Medicine and Jackson Memorial Hospital, Miami, FL, USA.

Published: 7 January 2014

doi:10.1186/1742-4690-11-S1-01

Cite this article as: Pimentel et al: Clinical features and outcome of adult T-cell leukemia/lymphoma: University of Miami experience. Retrovirology 2014 11(Suppl 1):01.
Submit your next manuscript to BioMed Central and take full advantage of:

- Convenient online submission

- Thorough peer review

- No space constraints or color figure charges

- Immediate publication on acceptance

- Inclusion in PubMed, CAS, Scopus and Google Scholar

- Research which is freely available for redistribution
() Biomed Central 